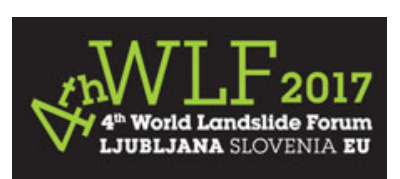

\title{
Geological Conservation Through Risk Mitigation and Public Awareness at the Siq of Petra, Jordan
}

\author{
Giorgia Cesaro, Giuseppe Delmonaco, Bilal Khrisat, and Sabrina Salis
}

\begin{abstract}
The Petra Archaeological Park, a UNESCO World Heritage Site since 1985, characterized by a spectacular geo-archaeological landscape, is also a fragile site facing a wide diversity of natural phenomena (landslides, flash floods, earthquakes) that pose a major threat to the heritage as well as to the visitors. The UNESCO Office in Amman, in partnership with the Department of Antiquities of Jordan and the Petra Archaeological Park has engaged in a long term strategy aimed at the prevention and mitigation of natural hazards at the site. Specific attention has been devoted to the case of the Petra Siq, a $1.2 \mathrm{~km}$ naturally formed gorge in the sandstone mountains serving as the only tourist entrance to the site, which is particularly at risk due to its narrow pathway, limited access points and recent active slope processes. Drawing on this approach, the UNESCO "Siq Stability" project has been developed to design a strategy towards prevention and mitigation of instability phenomena at the Siq of Petra. After an initial phase devoted to the reconstruction of geomorphological dynamics and monitoring of active slope processes, the current phase of the project focuses on the implementation of landslide risk mitigation measures, the capacity development of the national authorities and the development and implementation of an awareness strategy on natural hazards. Main focus has been placed on project activities undertaken, results achieved and suggestions for steps ahead, aiming to present a useful case study on the management of natural hazards applied to heritage sites leading to the conservation of a unique World Heritage property.
\end{abstract}

\section{Keywords}

Landslide risk - Community awareness - Petra archaeological park - UNESCO world heritage

G. Cesaro $(\bowtie) \cdot S$. Salis

Culture Sector, UNESCO Amman Office, Yacoub Ammari Street, Amman, 11181, Jordan

e-mail: g.cesaro@unesco.org

S. Salis

e-mail: s.salis@unesco.org

G. Delmonaco

ISPRA, Italian National Institute for Environmental Protection and Research, Via V. Brancati 48, 00144 Rome, Italy

e-mail: giuseppe.delmonaco@ isprambiente.it

B. Khrisat

Department of Conservation Sciences, Queen Rania Institute of Tourism and Heritage, Hashemite University, Zarqa, Jordan e-mail: bilal@hu.edu.jo

\section{Introduction}

In the last decades, the number of disasters and associated losses has been progressively increasing (IFRC 2015; Munich Re 2016).

In landslide risk management, non-structural measures, as community preparedness, public awareness and communication strategies, can be successfully applied to mitigate landslide risk especially in developing countries (Anderson 2013). Such strategies, along with the implementation of active measures for reducing landslide hazard, demonstrate the importance of involving the affected population and 
other stakeholders in the decision-making process for risk reduction (Nadim 2014).

According to the Hyogo Framework for Action 20052015, the main UN-wide policy on the subject of Disaster Reduction, increasing awareness on the importance of disaster reduction policies is a key objective to ensure the substantial reduction of disaster losses and enhance the resilience of communities to respond to disasters (UNISDR 2005).

Building on the Five Priorities for Action defined by the Hyogo Framework, the UNESCO World Heritage Committee approved at its 31st session in 2007 the Strategy for Risk Reduction at World Heritage properties having per objective to strengthen the protection of World Heritage sites and contribute to sustainable development by integrating concern for heritage into national disaster reduction policies and within management plans for World Heritage properties in their territories (UNESCO 2006).

The strategy was prepared by the World Heritage Centre, in co-operation with the States Parties, Advisory Bodies, and other international agencies and non-governmental organizations concerned by emergency interventions.

This same strategy is also reported on the Resource Manual on "Managing Disaster Risks at World Heritage Properties" produced by the World Heritage Centre in cooperation with ICCROM, ICOMOS and IUCN (UNESCO 2010).

In line with the above, in the last decade the UNESCO Office in Amman has engaged in the implementation of activities geared towards ensuring that preventive measures are in place in the main touristic areas of the site, and, specifically, in the Siq, so to evaluate how the site can best be protected and preserved against natural risks and ensure that it is safe for the thousands of tourists who visit each year

\section{Scope of Work}

The archaeological site of Petra (Fig. 1) lies in a large valley surrounded by mountain ranges. Its geology is dominated by Palaeozoic sandstone rocks that form most of the hand-carved Nabataean rock monuments of Petra. The Siq is a $1.2 \mathrm{~km}$ naturally formed gorge in the sandstone rocks that represents the main entrance to the archaeological site. Because of the religious niches and water management features, the Siq, in its entirety, is considered as a monument of religious and historic significance, considerably contributing to the Outstanding Universal Value of Petra. The width of the Siq ranges from $3 \mathrm{~m}$ to $15.70 \mathrm{~m}$. It is formed by very steep slopes with variable height from the ground level, from few meters at the entrance to several tens of meters in some areas of the path.
Petra is also a very fragile site facing a wide diversity of risks, ranging from those posed by environmental factors, such as natural and geological hazards, as well as those attributed to tourism and the lack of adequate site management and emergency measures for tourist and monument safety. In recent years, natural phenomena, such as earthquakes, floods and landslides were registered as increasingly impacting the site, and most specifically the Siq posing a major threat to cultural heritage and visitors.

During the rainy season, water flows into the Siq from the surrounding wadis. In 1963, 24 tourists died as a result of a sudden flash-flood in the Siq. Water management and the hydraulic system created by the Nabataeans, protected the monuments and the people from life threatening flash-floods, however those systems are now deteriorated and no longer protecting the site or visitors. A survey of the Nabataean hydraulic network in the Siq and the areas with direct impact on the Siq was conducted from 1996 to 2002 (PNT 2003). As a result of this project, the velocity of water flow during flash floods was reduced by restoring the existing floor of the Siq to its original pavement and grade.

Despite this intervention, the risk posed by landslides is still present in the Siq due to its specific geomorphology. In the last decade, several landslide events, mostly rock falls and rock slides, with different magnitude (volumes from $<1$ to $\left.>10 \mathrm{~m}^{3}\right)$ have occurred in the Siq $(2009,2015)$ and in the core area of the site $(2009,2010,2016)$.

These recent events have prompted UNESCO Amman Office, in cooperation with the local authorities, to initiate a process for analysis, monitoring and urgent and long-term mitigation of landslide risk. Awareness and communication activities on natural hazards have been among the non-structural mitigation strategies implemented.

\section{UNESCO Petra Risk Assessment and Mitigation Strategies}

Preserving Petra's Outstanding Universal Value for which the site has been inscribed in the World Heritage List (UNESCO 2016), is one of the corporate UNESCO priorities for culture actions in Jordan, in line with the UNESCO Strategy for Risk Reduction at World Heritage properties (UNESCO 2006).

Since 2009, the UNESCO Office in Amman has supported the Petra Archaeological Park and the Department of Antiquities in assessing, managing and mitigating natural hazards in Petra World Heritage site.

Within the framework of the project "Risk Mapping at the Petra Archaeological Park" (2011-2012), a strategic partnership was established with the government and several partner organizations, including national and international 


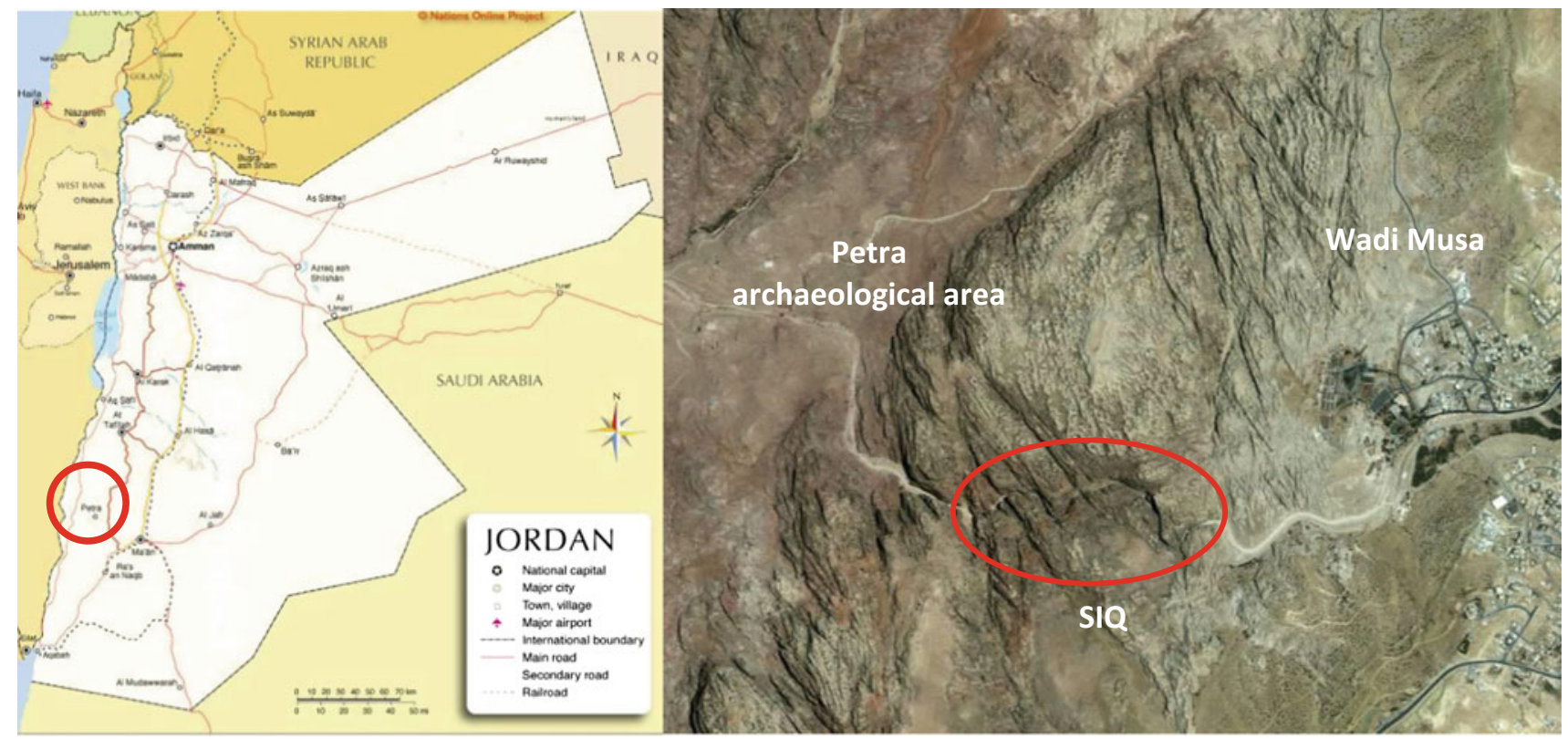

Fig. 1 Location of Petra (left) and satellite image of the Siq (red circle) and Petra archaeological area

universities, to map and document the natural and human-made risks in the core area of the property. A proposal for risk management at the Petra Archaeological Park to identify and prioritize continuous threats with cumulative and slow effects (not disaster risks) was elaborated and handed over to the government in 2012 (Paolini et al. 2012).

From 2009 to 2015, UNESCO engagements focused on addressing for the first time the impact of landslides phenomena in the Siq. In 2009 a technical expertise in engineering geology was provided to the national authorities to support the consolidation of a fractured block in the Siq.

Through the implementation of the projects "Rapid Risk Assessment" (2011) and "Siq Stability", Phase I (20092015) actions have been focusing on the analysis of the stability conditions of the Siq slopes based on a comprehensive documentation of the site, the installation of an integrated monitoring system for the detection and control of deformation processes and the definition of mitigation measures against rock instability (Delmonaco et al. 2013a, b, c, 2014, 2015).

The Petra "Siq Stability" project Phase II (2015-2016) aims to operationally implement the mitigation of landslide risk in the Siq through the (a) application of priority and urgent landslide mitigation interventions in the upper Siq plateau and on the Siq slopes to address immediate slope hazards in the short term; (b) capacity development of the national authorities to address the management of landslide risk at the site and implement mitigation measures in coordination with international experts; (c) awareness raising among different levels of stakeholders on landslide and other natural hazards occurring within the Petra Archaeological Park and specifically in the Siq.

Public awareness and communication among a broad set of stakeholders, ranging from decision makers to the local community, fall into the third project component as non-structural mitigation strategies against natural hazards and shall be later incorporated into a wider management strategy for the site.

\section{Risk Awareness Methodology and Implementation in Petra}

The local community and the tourists are generally unaware of how the geological and hydraulic processes that shaped spectacular landscapes can be hazardous to people. Informed visitors can instead assume a certain degree of risk and responsibility for their own safety when visiting natural, cultural or recreational environments. In view of this, park public safety programs shall involve the communication of site-specific hazards to visitors, education and information programs that encourage self-reliance, cooperation with other departments, non-governmental organizations, tourism operators, concessionaires, and service providers (NPS 2006).

Data gathered showed that awareness of natural risks preparedness and mitigation, mostly at the community level, can be the foundation for risk prevention in Petra. Stakeholders and local communities can play a key role in the management of a geo-archaeological site, in particular in relation to disaster risk reduction. 
The approach adopted in the "Siq Stability" project aims at supporting the Petra Archaeological Park in raising awareness on heritage management and conservation, focusing on natural risks preparedness and mitigation. Different typologies of stakeholders were identified (decision makers, governmental institutions, NGOs and UN agencies, professionals/researchers, site business beneficiaries, tour guides, children, local community) and a set of targeted activities was selected for each of them (Table 1).

Overall, the strategy aims at: (a) achieving best practices on preservation and management of the site supported and endorsed by the national authorities; (b) making local communities, site beneficiaries, and other stakeholders engaged in the site with different capacities, aware of the activities undertaken in the Siq for the prevention of natural hazards; (c) ensuring that best practices are adopted by tourists when visiting the Siq in regards to the impact of natural hazards that might occur on site; (d) making the international community and the national authorities aware of the work that UNESCO is conducting in the Siq.

In parallel to the priority landslide mitigation interventions carried out in the upper Siq plateau and on the Siq slopes from March to July 2016, as part of the project "Siq Stability", Phase II, a number of communication and public awareness activities on geological and geo-hydrological hazards were implemented, according to the strategy developed.

While some of the stakeholders' categories could be addressed through convening meetings or field visits (decision makers, NGOs, UN agencies), some others required specific outreach methodologies because of their primary involvement during the implementation of the landslide risk mitigation works on site, as in the case of tourists, tour guides, site business beneficiaries and local communities. The type of activities implemented varied in relation to the target group addressed and the timing of implementation (before or during the field works).

In order to ensure effective and efficient implementation, a comprehensive coordination and management system was set in place in cooperation with the Petra Archaeological Park in advance of each field mission and according to a preliminarily agreed check-list of actions.

Before the implementation of the field activities, community awareness workshops involving site business beneficiaries and tour guides from the local community were carried out in coordination with the project experts and the local authorities. The primary aim of the workshops was to raise awareness on the geomorphological and hydraulic hazards characterizing the Siq, promote a more responsible behavior conducive to risk prevention and, thus, ensure their cooperation during the upcoming field activities. This measure would apply to business beneficiaries as horse-driven carriage riders transporting tourists unrelentingly from the beginning to the end of the Siq, often at high speed and with limited interest in the surrounding environment: having them informed on the specificity of the site and possible natural hazards can enhance their sense of responsibility and produce a transfer of information to the visitors.

As part of the actions taken before the implementation of works, communication materials as project brochures and
Table 1 Overview of target groups and related activities

\begin{tabular}{|c|c|c|c|c|c|c|}
\hline \multirow[t]{2}{*}{ Target groups } & \multicolumn{6}{|c|}{ Type of activities } \\
\hline & $\begin{array}{l}\text { Field visits } \\
\text { Technical } \\
\text { meetings } \\
\text { Workshops }\end{array}$ & $\begin{array}{l}\text { Informal } \\
\text { meetings } \\
\text { and site } \\
\text { visits }\end{array}$ & $\begin{array}{l}\text { Informative } \\
\text { material (ENG } \\
\text { and ARB) }\end{array}$ & $\begin{array}{l}\text { Presentations } \\
\text { Lectures }\end{array}$ & $\begin{array}{l}\text { Workshop } \\
\text { High level } \\
\text { conference }\end{array}$ & $\begin{array}{l}\text { Interactive } \\
\text { sessions }\end{array}$ \\
\hline $\begin{array}{l}\text { 1. Decision } \\
\text { makers }\end{array}$ & & & & & $\mathrm{X}$ & \\
\hline $\begin{array}{l}\text { 2. Other Gov. } \\
\text { institutions }\end{array}$ & $\mathrm{X}$ & & & & & \\
\hline $\begin{array}{l}\text { 3. NGOs and } \\
\text { UN agencies }\end{array}$ & $X$ & & & & & \\
\hline $\begin{array}{l}\text { 4. Professionals } \\
\text { researchers }\end{array}$ & & & $\mathrm{X}$ & $\mathrm{X}$ & & \\
\hline $\begin{array}{l}\text { 5. Site } \\
\text { beneficiaries }\end{array}$ & & $X$ & & & & \\
\hline 6. Tour guides & & $\mathrm{X}$ & & & & \\
\hline $\begin{array}{l}\text { 7. Local } \\
\text { community }\end{array}$ & & $\mathrm{X}$ & $X$ & & & \\
\hline 8. Children & & & $\mathrm{X}$ & & & $X$ \\
\hline 9. Tourists & & & $\mathrm{X}$ & & & \\
\hline
\end{tabular}


informative flyers were disseminated to the hotel management units within the surrounding village of Wadi Musa and a warning on the upcoming activities was posted on the Petra Archaeological Park web site.

During the landslide risk mitigation works (Fig. 2), awareness raising activities were performed on site and focused on public awareness with tourists and site business beneficiaries. Ad hoc awareness materials on the project were prepared for distribution at the Petra Visitor Centre (project flyers, Fig. 3).

The same materials were distributed to tourists in the Siq, at the beginning and at the end of the work site. Access to the work area (normally about $30 \mathrm{~m}$ in length) was temporarily blocked for tourists by using white and red striped tape and placing project banners (Fig. 4).

Dedicated UNESCO and Petra Archaeological Park staff stood at the beginning and at the end of the work site to share project flyers and provide general information on the activities being implemented (Fig. 5). The project team could also rely on the substantial support provided by the Jordan Civil Defense, the Petra Archaeological Park rangers

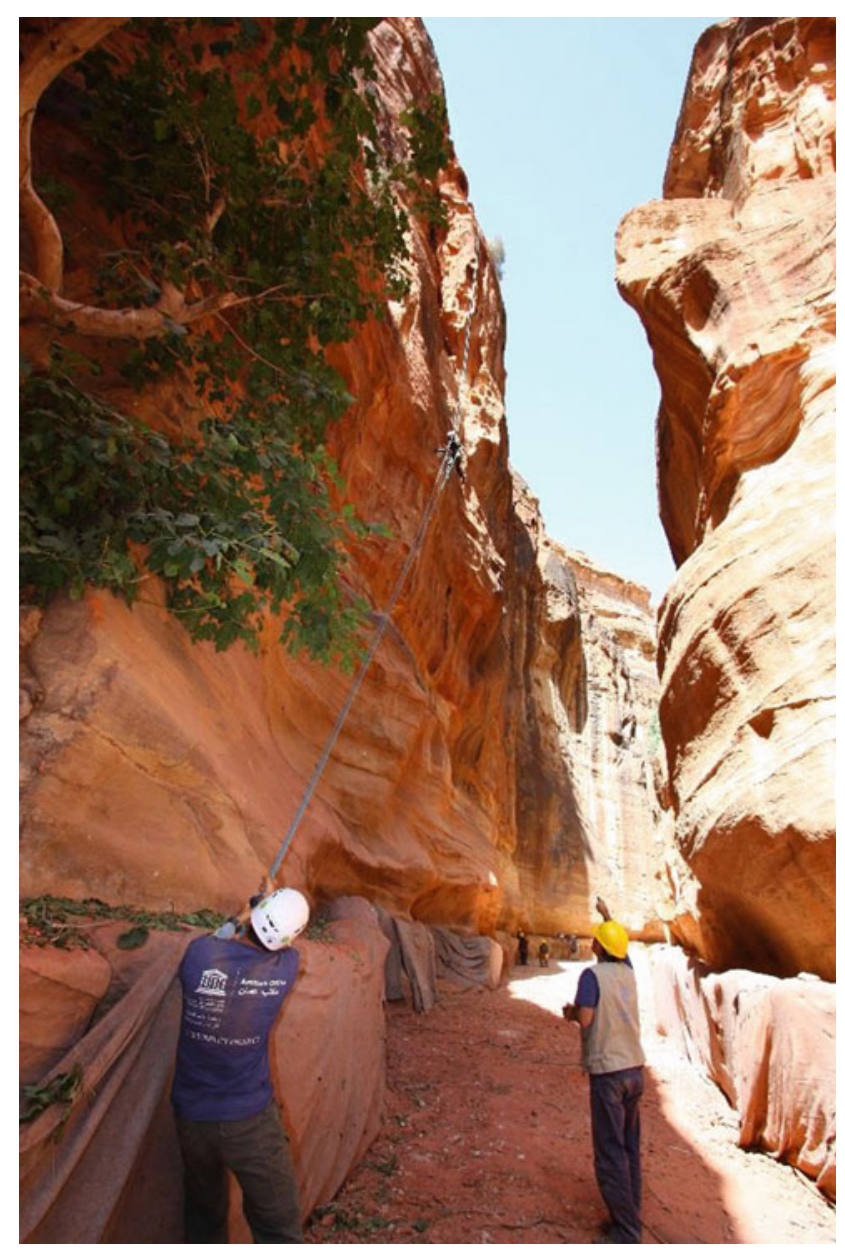

Fig. 2 Landslide risk mitigation works

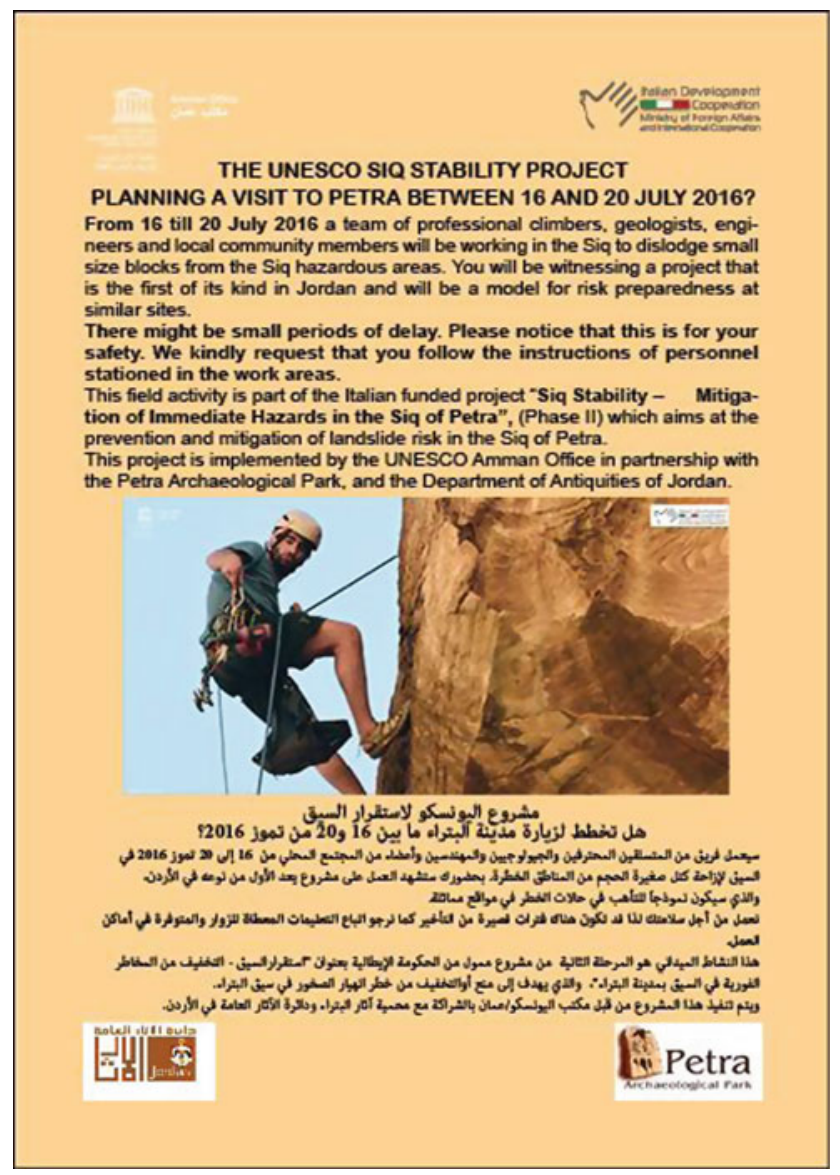

Fig. 3 Flyer of the risk mitigation works 2016

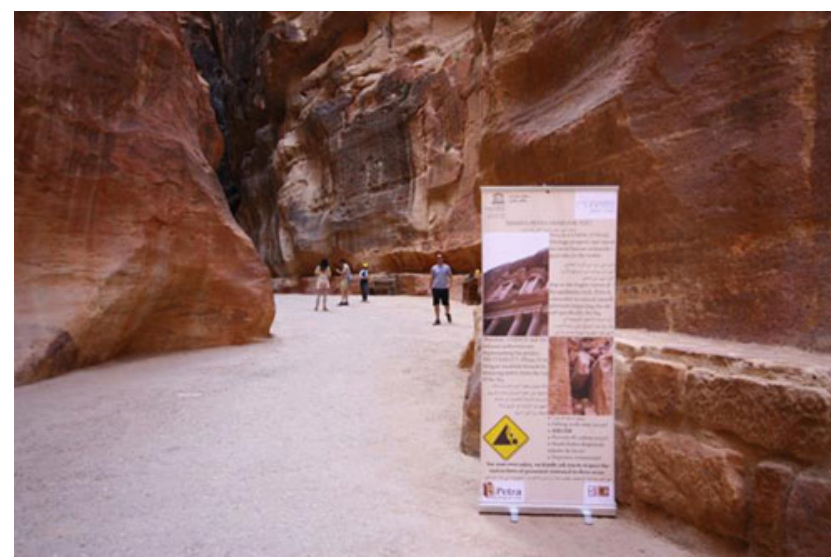

Fig. 4 Banner of the risk mitigation works 2016

and the Tourism Police, whom engaged in public awareness activities with the tourists and the local community alongside their more institutional duties.

The whole project team, from the project experts to the workmen (all belonging to the local community) were involved in communicating with the general public on the risk stability phenomena present in the Siq. 


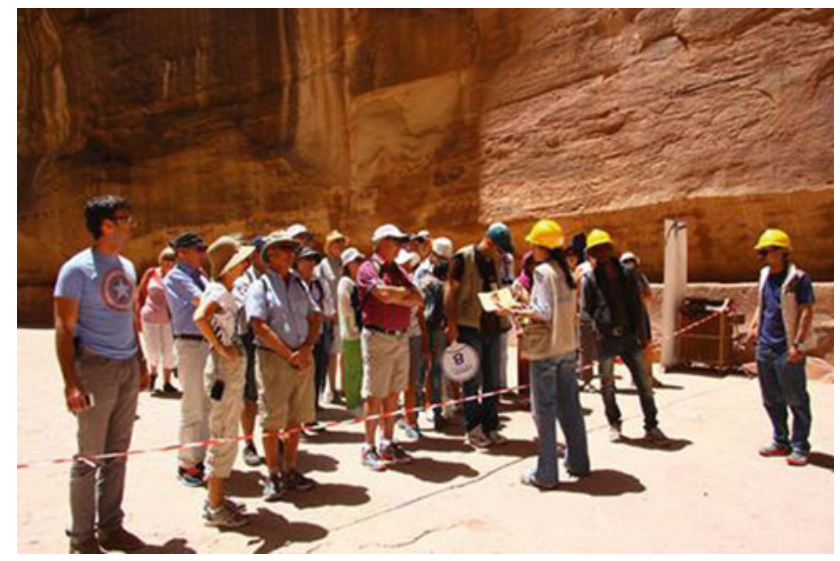

Fig. 5 Communication session on landslide mitigation works to visitors

Future actions (September-December 2016) will be targeting those categories that have not been yet recipient of the awareness programme as children and school students among the local communities surrounding the Petra Archaeological Park.

It is foreseen that the final achievements of this work will be compiled and integrated in the management plan for the whole site, whose preparation is currently being developed by UNESCO and the local authorities.

\section{Conclusions}

This study demonstrates the essential role that public awareness and communication on natural hazards can play as non-structural technique in the management and mitigation of landslide risk in the Siq of Petra and further support the Petra Archaeological Park in the management of environmental risks at the site.

Despite the time limitations, project related experience reported and the challenges faced in the management of the tourist flow at one of the most visited sites in the world, this initiative can be regarded as a successful example of cooperation between the national authorities and UNESCO for the improved management of a World Heritage Site.

Similar actions shall be then integrated in a management plan for the protection of the site for which is currently being elaborated by UNESCO Amman in cooperation with the national authorities.
Acknowledgements This study has been conducted in the framework of the UNESCO, Italian funded, project "Siq Stability-Mitigation of Immediate Hazards in the Siq of Petra" (Phase II). A special acknowledgement is, thus, addressed to the Italian Development Cooperation for having entrusted the UNESCO Amman Office with the implementation of such a strategic project at the Petra World Heritage Site.

The authors wish also to acknowledge the substantial support provided by the Government of Jordan represented by the Petra Archaeological Park and the Department of Antiquities for their continuously cooperation in the implementation of this pioneering project.

\section{References}

Anderson MG (2013) Landslide risk reduction in developing countries: perceptions, successes and future risks for capacity building. In: Canuti P, Margottini C, Sassa K (eds) Landslide science and practice. Social and economic impact and policies, vol 7. Springer, Heidelberg, pp 247-256. ISBN 978-3-632-31312-7

Delmonaco G, Margottini C, Spizzichino D (2013a) Rock-fall hazard assessment in the Siq of Petra, Jordan. In: Canuti P, Margottini C, Sassa K (eds) Landslide science and practice. Risk assessment, management and mitigation, vol 6. Springer, Heidelberg, pp 441449. ISBN 978-3-632-31312-6

Delmonaco G, Margottini C, Spizzichino D (2013b) Slope dynamics, monitoring and geological conservation of the Siq of Petra (Jordan). In: Bilotta E, Flora A, Lirer S, Viggiani C (eds) Geotechnical engineering for the preservation of monuments and historic sites. Taylor \& Francis Group, London, pp 325-334. ISBN 978-1-138-00055-1

Delmonaco G, Margottini C, Spizzichino D (2013c) Slope dynamics, monitoring and geological conservation of the Siq of Petra (Jordan). In: Canuti P, Margottini C, Sassa K (eds) Landslide science and practice. Risk assessment, management and mitigation, vol 6 . Springer, Heidelberg, pp 441-449. ISBN 978-3-632-31312-6

Delmonaco G, Margottini C, Spizzichino D, Khrisat B (2014) Rock slope potential failures in the Siq of Petra (Jordan). In: Sassa K, Canuti P, Yueping Y (eds) Landslide science for a safer geoenvironment. Targeted landslides, vol 3. Springer, pp 341-347. ISBN 978-3-319-04995-3

Delmonaco G, Leoni G, Margottini C, Spizzichino D (2015) Implementation of advanced monitoring system network in the Siq of Petra (Jordan). In: Lollino et al G (eds) Engineering geology for society and territory, vol 8 . Springer, Cham, pp 299-303. ISBN 978-3-319-09407-6

International Federation of Red Cross and Red Crescent Societies (2015) World disaster report. In: Hanza M (ed) ISBN 978-92-9139-226-1, p 270

Munich Re (2016) Topics Geo-Annual review of natural catastrophes 2015. Analyses, assessments, positions. https://www.munichre. com/site/corporate/get/documents_E1273659874/mr/assetpool. shared/Documents/5_Touch/_Publications/302-08875_en.pdf. Last accessed 30 Aug 2016

Nadim F (2014) Introduction: risk reduction strategy. In: Sassa K, Canuti P, Yueping $\mathrm{Y}$ (eds) Landslide science for a safer 
geoenvironment. Methods of landslide studies, vol 2. Springer, pp 743-744. ISBN 978-3-319-05049-2

Paolini A, Vafadari A, Cesaro G, Santana Quintero M, Van Balen K, Vileikis O, Fakhoury L (2012) Risk management at heritage sites: a case study of the Petra world heritage site. UNESCO, Amman. ISBN 978-92-3-001073-7

PNT (2003) The Petra Siq: nabataean hydrology uncovered. Petra National Trust, Amman. ISBN deposit number 2003-6-1223

UNESCO (2006) Issues related to the state of conservation of world heritage properties: strategy for reducing risks from disasters at world heritage properties, adopted by the Committee at in 30th session. WHC-06/30, COM/7.2, Vilnius, p 1. http://whc.unesco.org/ en/disaster-risk-reduction/\#strategy. Last accessed 30 Aug 2016

UNESCO (2010) Managing disaster risks for world heritage. http:// whc.unesco.org/en/managing-disaster-risks/. Last accessed 30 Aug 2016

UNESCO (2016) World Heritage Centre, Petra world heritage site. http://whc.unesco.org/en/list/326. Last accessed 30 Aug 2016

UNISDR (2005) The hyogo framework for action 2005-2015: building the resilience of nations and communities to disasters at the world conference on disaster reduction. http://www.unisdr.org/2005/wcdr/ intergover/official-doc/L-docs/Hyogo-framework-for-actionenglish.pdf. Last accessed 30 Aug 2016
Open Access This chapter is licensed under the terms of the Creative Commons Attribution 4.0 International License (http:// creativecommons.org/licenses/by/4.0/), which permits use, sharing, adaptation, distribution and reproduction in any medium or format, as long as you give appropriate credit to the original author(s) and the source, provide a link to the Creative Commons license and indicate if changes were made.
The images or other third party material in this chapter are included in the chapter's Creative Commons license, unless indicated otherwise in a credit line to the material. If material is not included in the chapter's Creative Commons license and your intended use is not permitted by statutory regulation or exceeds the permitted use, you will need to obtain permission directly from the copyright holder. 